\title{
Effect of Storage on Quality Characteristics of Pasteurized Mango Based Milk Beverage
}

\author{
Preeti Shukla $^{1 *}$, Usha Bajwa ${ }^{1}$ and Suresh Bhise ${ }^{2}$ \\ ${ }^{1}$ Department Food Science and Technology, Punjab Agricultural University, \\ Ludhiana-141004, Punjab, India \\ ${ }^{2}$ College of Horticulture, Anand Agricultural University, Anand-388110, Gujarat, India \\ *Corresponding author
}

\section{A B S T R A C T}

Keywords

Effect of storage, Quality, Pasteurized mango.

\section{Article Info}

Accepted:

26 September 2017

Available Online:

10 November 2017
An investigation was carried out to evaluate the effects of packaging and storage conditions on the mango based pasteurized dairy beverage. The beverage was prepared using milk $(0.5 \%$ fat $)$, sugar $(6.0 \% \mathrm{w} / \mathrm{w})$ and mango pulp $(30 \% \mathrm{w} / \mathrm{w})$ and packaged in HDPE sachets. It was then pasteurized and stored under refrigeration. The study revealed a significant increase in acidity and reducing sugars. There was a significant decrease in antioxidant activity, HMF concentration, $\mathrm{pH}$, total sugars, ascorbic acid content and overall acceptability of the beverage. The beverage showed an increased microbial count making the beverage unacceptable after six days of storage.

\section{Introduction}

At present fruit beverages are generally synthetic flavored, bottled and sold in the market. If this could be substituted with fruit pulp and milk, it will be more beneficial to the consumer, dairy industries and beverage manufacturers and fruit growers. The development of nutritionally value added product could therapeutically help on improving the health of consumers. Mango pulp and milk can be utilized to make the product therapeutic, prophylactic and nutritionally rich which may increase its demand in food and beverage industry. Mango (Mangifera indica L.) is one of the favored fruits in the tropical and sub-tropical regions. It has an excellent flavor, attractive fragrance, delicious taste and high nutritional value that have made it one of the best fruits. The researchers reported preparation of fruit flavored beverages using whey obtained from coagulation of cow milk, Gajarani et al., (1986).

Singh et al., (1994) formulated a whey based mango beverages with $15 \%$ pulp and $78 \%$ whey. Soft beverage from paneer whey and guava was developed by Singh et al., (1994) while Sikder et al., 2001, formulated different blends of whey beverages by using various levels of mango pulp (8-12\%) of four different varieties. India has plenty of fruits that are a good source of vitamins and 
minerals. As production of fruits is seasonal, there is a glut in the market during a particular season. Mangos are high in fiber, but low in calories (approx. 110 per average sized mango), traces amount of fat and sodium. During market glut in the season, the pulp/juice can be processed and used further.

Beverages based on fruits and milk products are currently receiving considerable attention as their market potential is growing. Besides being delicious, these beverages are highly nutritious. Therefore, to make the best use of dairy whey and mango fruit, the present study was conducted to develop delicious and nutritious beverages from the combinations of fruit pulp and milk products.

\section{Preparation of mango flavoured milk beverage}

The process of preparation of mango flavoured milk beverage is presented in Figure 1. RSM was used to optimize the level of ingredients. It was found that 0.5 per cent milk fat (v/v), 6.0 per cent sugar $(\mathrm{w} / \mathrm{v})$ and 30.0 per cent mango pulp yielded the beverage with maximum antioxidant activity and highest acceptability. Hence, these levels were used for further studies. The drinks were heated to $65{ }^{\circ} \mathrm{C}$ with constant stirring, filtered through a muslin cloth to remove fibres, if any, homogenized at $2000 \mathrm{psi}$, filled in HDPE packaging material $(200 \mathrm{ml})$ or sterilized glass bottles $(200 \mathrm{ml})$, sealed, labeled and pasteurized at $80{ }^{\circ} \mathrm{C}$ for $5 \mathrm{sec}$ and cooled to $5.0{ }^{\circ} \mathrm{C}$. These bottles were stored under refrigeration at $5.0 \pm 0.1^{\circ} \mathrm{C}$.

\section{Storage studies}

The stored samples were evaluated for physico-chemical changes and sensory attributes at regular time intervals. The pasteurized samples were subjected to analyses at an interval of two days whereas the sterilized ones were evaluated after 15 days. The samples stored at room temperature were also chilled before subjecting to organoleptic evaluation.

\section{Physico-chemical analyses}

Milk, mango pulp and prepared milk drinks were analyzed for physico-chemical parameters using AOAC (2000) procedures. For each parameter, the samples were analysed in three replications.

\section{Moisture}

Moisture content was determined by AOAC (2000) method. Five gram sample was dried to a constant weight at $100 \pm 1{ }^{\circ} \mathrm{C}$ in a moisture dish. The loss in weight was used to calculate per cent moisture content.

\section{Protein}

Total nitrogen in the sample was determined by Micro Kjeldahl method of AOAC (2000). A conversion factor of 6.38 was used for calculating crude protein content of milk and milk drinks.

\section{Fat}

For estimation of fat content in milk and milk drinks, Gerber's method (BIS, 1981) was used whereas Soxhlet method (AOAC, 2000) was followed for estimation of fat in mango pulp. Weighed sample (10 g) was extracted with petroleum ether $\left(60-80^{\circ} \mathrm{C}\right)$ in a Soxhlet apparatus for 16 hours. The extract containing fat and petroleum ether was evaporated over steam bath, dried in an oven at $50{ }^{\circ} \mathrm{C}$, weighed and per cent fat was calculated.

\section{Ash}

AOAC (2000) procedure was adopted for determination of ash content. Total ash content was expressed as percentage. 


\section{Total soluble solids $\left(\mathrm{TSS}^{\circ} \mathrm{B}\right)$}

Hand refractometer (Erma, Japan) with a scale range of 0 to 32 per cent was used to determine TSS of mango pulp and milk drink samples at $20^{\circ} \mathrm{C}$.

\section{Sugars}

Lane and Eynon method of AOAC (2000) as described by Ranganna (1994) was used for determining reducing and total sugars in milk drink samples.

\section{Total sugars}

Twenty $\mathrm{ml}$ of milk drink was taken in a 250 $\mathrm{ml}$ volumetric flask and to this $100 \mathrm{ml}$ distilled water was added. It was neutralized with $1 \mathrm{~N}$ sodium hydroxide using phenolphthalein as indicator. To this, $2 \mathrm{ml}$ lead acetate solution ( 45 per cent) was added, shaken well and allowed to stand for $10 \mathrm{~min}$. Thereafter, $5 \mathrm{ml}$ of potassium oxalate solution (22 per cent) was added and volume made up with distilled water. This solution was filtered and marked as "A". This filtrate was titrated directly with $10 \mathrm{ml}$ Fehling solution using methylene blue as indicator.

\section{Total sugars}

Twenty five $\mathrm{ml}$ of filtrate "A" was taken in a $250 \mathrm{ml}$ conical flask and approximately $50 \mathrm{ml}$ distilled water was added to it. Then $5 \mathrm{~g}$ citric acid was added and dissolved in it. This solution was boiled vigorously for $10 \mathrm{~min}$. for inversion of sugars. It was cooled and then transferred completely to a $250 \mathrm{ml}$ volumetric flask for control drink and $100 \mathrm{ml}$ volumetric flask for sample drink, with distilled water. It was then neutralized with saturated $\mathrm{NaOH}$ solution and volume was made with distilled water. This solution was marked as " $\mathrm{B}$ " and was used to determine total sugars by titration using Fehling solution and methylene blue as indicator.
pH

The $\mathrm{pH}$ of all the samples was determined using pocket $\mathrm{pH}$ meter (IQ Scientific, USA. Model IQ 125).

\section{Acidity}

The titratable acidity of milk and milk drinks was determined by titrating $10 \mathrm{ml}$ of sample against $0.1 \mathrm{~N} \mathrm{NaOH}$. The results were expressed as per cent lactic acid. Titratable acidity of mango pulp was determined as per AOAC (2000) procedure and expressed as per cent citric acid.

\section{Ascorbic acid}

Ascorbic acid was extracted from the samples (10g) with 0.4 per cent oxalic acid (Ruck 1969) and the titrimetric method as described by Ranganna (1994) using 2, 6dichlorophenol-indophenol dye was followed.

\section{Viscosity}

Dynamic viscosity in centipoise $(\mathrm{cP})$ of all the milk drinks was measured at $20{ }^{\circ} \mathrm{C}$ using the Hoppler Viscosimeter (design type BH2). The time of fall of a ball in a cylindrical tube (internal diameter $=15.94 \mathrm{~mm}$ ) inclined by $10^{\circ}$ with respect to the vertical plane and filled with the beverage to be examined, was recorded. Ball no. 3 was used to measure the dynamic viscosities of drinks containing mango pulp whereas ball no. 1 was used for all other milk drinks. The time taken by the ball to fall from first annular mark to the last annular mark (distance of fall $=100 \mathrm{~mm}$ ) was noted using a stopwatch.

The calculation of the dynamic viscosity was performed using the following formula:

$\eta=t X\left(\rho_{1}-\rho_{2}\right) X K$

$\eta=$ dynamic viscosity in $\mathrm{cP}$ 
$\mathrm{t}=$ fall time of the ball in $\sec (\mathrm{s})$

$\rho_{1}=$ density of the ball at measurement temperature in $\mathrm{gcm}^{-3}$ (ball no. $1=2.404 \mathrm{gcm}^{-}$

${ }^{3}$; ball no. $3=8.10 \mathrm{gcm}^{-3}$ )

$\rho_{2}=$ density of the sample liquid at measurement temperature in $\mathrm{gcm}^{-3}$.

$\mathrm{K}=$ ball constant in $\mathrm{cP} . \mathrm{cm}^{3} \cdot \mathrm{g}^{-1} \cdot \mathrm{s}^{-1}$ (ball no. $1=$ 0.009956 ; ball no. $3=0.1351$ )

\section{Antioxidant activity}

Antioxidant activity was estimated using standard procedure of DPPH (2, 2-diphenyl1picrylhydrazyl) assay (Tepe et al., 2006). Six $\mathrm{ml}$ of DPPH solution $(0.2 \mathrm{mM}$ in $80 \%$ methanol) was mixed with $2.0 \mathrm{ml}$ of each sample. The samples were incubated for 30 min in dark at room temperature $\left(25 \pm 2{ }^{\circ} \mathrm{C}\right)$. The absorbance (A) was measured at $518 \mathrm{~nm}$ by using Spectronic-20 (Bausch and Lomb, USA) Spectrophotometer. The percentage of the radical scavenging activity was calculated as percentage inhibition of DPPH radicals using the following equation:

$\%$ inhibition of DPPH $=\frac{[\text { A control }- \text { Asample }] \times 100}{A \text { control }}$

Where, A is Absorbance

Two $\mathrm{ml}$ methanol (80\%) plus $6.0 \mathrm{ml}$ distilled water was used as a blank. For the control, DPPH solution replaced distilled water.

\section{HMF estimation}

HMF was estimated using the procedure of Morales et al., (2002), with slight modification. Twenty $\mathrm{ml}$ samples of wellmixed milk ingredients were subjected to different heat treatments and cooled rapidly in ice bath. Thereafter samples were slowly deproteinized with $10 \mathrm{~mL}$ of trichloroacetic acid solution (TCA) $(10 \%, w / v)$, centrifuged and filtered through Whattman No.42 filter paper. Ten ml filtrate was taken in separating funnel and extracted with $20 \mathrm{ml}$ ether thrice. The extracts were combined and again filtered through Whattman No.1 filter paper.

To $3 \mathrm{ml}$ filtrate, add $3 \mathrm{ml}$ ethanol (99.99\%) and $1 \%$ resorcinol in $\mathrm{HCl}$. It was mixed well and stored in dark for $30 \mathrm{~min}$ at ambient temperature $\left(25 \pm 1^{\circ} \mathrm{C}\right)$ for the development of reddish pink color. The absorbance was measured at $540 \mathrm{~nm}$ using Spectronic-20 spectrophotometer. The concentrations of HMF in the samples were calculated from standard curve of HMF.

\section{Preparation of standard curve}

Prepared using concentrations ranging from 0 to $180 \mathrm{mg} / \mathrm{ml}$. The amount of HMF was obtained as $\mathrm{mg} / 100 \mathrm{~g}$ using the formula:

HMF $(\mathrm{mg} / 100 \mathrm{~g})=\frac{\text { Concfrom standard curve x Dilution factor }}{\text { Volume taken for color development } x \text { Sample wt(gm) }}$

\section{Microbiological studies}

Standard plate count (SPC), yeast and mould count (YMC) and psychrophillic counts were recorded as per APHA (1984) procedures using nutrient agar and glucose yeast extract agar respectively.

\section{Sensory evaluation}

\section{Hedonic rating}

All of the milk drink samples were evaluated for appearance/colour, flavour, body and mouthfeel and overall acceptability by a semitrained panel of eight judges from the department using a nine point hedonic scale with scores ranging from liked extremely (9) to disliked extremely (1) (Meilgaard et al., 1999). The overall acceptability scores were calculated by taking mean of all the three attributes for each sample. 


\section{Statistical analysis}

The data collected from the standardization and storage studies were subjected to the analysis of variance (Snedecor and Cochran, 1968), and factorial experiment in CRD (Critical Randomized Design) using CPCS1 software developed by the Department of Mathematics, Statistics and Physics, Punjab Agricultural University, Ludhiana, Punjab.

\section{Results and Discussion}

\section{Proximate analysis of milk and mango pulp}

The data pertaining to the various chemical characteristics of whey and mango pulp are presented in Table 1 . It clearly indicates that whey and mango pulp were as expected rich in SNF and ascorbic acid respectively. Mango pulp was found better in TSS, total and reducing sugars contents whereas whey was better in protein, SNF, fat and total solids. The results obtained with respect to chemical characteristic are in agreement with the earlier studies

\section{Effect of storage on physico-chemical parameters}

Changes during storage on physico-chemical parameters of mango based dairy beverage were studied and obtained results are presented in Table 2. Physico-chemical properties of beverages such total solids, total soluble solids, $\mathrm{pH}$, reducing sugars, acidity, ascorbic acid, antioxidant activity, HMF concentration and viscosity were affected significantly as the duration of storage progressed.

The effect of refrigerated storage $\left(5.0 \pm 0.1^{\circ} \mathrm{C}\right)$ on physicochemical characteristics of pasteurized mango flavoured milk beverage is presented in Table 2. The TS, TSS, $\mathrm{pH}$, acidity, reducing sugars and ascorbic acid content differed significantly $(\mathrm{p}<0.05)$ both in HDPE sachets as well as glass bottles during storage.

In the beverage packaged in HDPE sachets, the total solids content reduced significantly $(\mathrm{p}<0.05)$ from 12.79 to 11.94 and 15.91 to $14.84, \mathrm{pH}$ values lowered from 6.86 to 6.15 and 6.57 to 5.99 , reducing sugar content from 4.41 to 4.15 and 4.42 to 4.25 per cent, ascorbic acid from 1.287 to 0.935 and 1.661 to $0.943 \mathrm{mg} / 100 \mathrm{~g}$ for control and experimental beverage respectively. The total soluble solids (TSS) increased significantly $(\mathrm{p}<0.05)$ from 11.64 to 12.51 and 12.68 to 13.57, titratable acidity (per cent lactic acid) from 0.126 to 0.136 and 0.139 to 0.236 for control and experimental beverage, respectively. Viscosity of the drinks decreased significantly $(\mathrm{p}<0.05)$ from 1.59 to 1.39 and 1.63 to $1.46 \mathrm{cP}$, antioxidant activity (per cent inhibition of DPPH) from 30.89 to 25.19 and 42.39 to 39.06 and HMF concentration from 149.55 to 119.54 and 152.72 to $129.45 \mu \mathrm{g} / 100 \mathrm{~g}$ for control and experimental beverages, respectively.

In the pasteurized experimental beverage packaged in glass bottles, total soluble solids (TSS) showed an overall increase from 11.64 to 12.43 and 12.66 to 13.30 . The titratable acidity (per cent lactic acid) increased significantly $(p<0.05)$. The initial acidities were 0.126 and 0.145 for control and experimental beverage, respectively which increased to 0.141 and 0.230 per cent. The total solids content reduced significantly $(\mathrm{p}<0.05)$ from 12.57 to 11.63 and 15.50 to $14.72, \mathrm{pH}$ values decreased from 6.50 to 5.90 and 6.30 to 6.10 , reducing sugar content from 4.38 to 3.93 per cent and 4.42 to 4.00 per cent in control and experimental beverage, respectively. The added sugar may be a source of microbial spores in the samples. These spores along with available microflora converted the reducing sugars into acid during 
storage. The ascorbic acid content decreased significantly $(\mathrm{p}<0.05)$ from 1.296 to 0.563 $\mathrm{mg} / 100 \mathrm{~g}$ for control and 1.623 to 0.582 $\mathrm{mg} / 100 \mathrm{~g}$ for experimental beverage. This might be due to loss of ascorbic acid during storage due to auto-oxidation and light effect. According to DeMan (1990) ascorbic acid is the least stable of all the vitamins and is easily destroyed during processing and storage. A noticeable decline in the ascorbic acid content of muskmelon RTS beverage during six months storage was also noticed by Teotia et al., (1997). Njoku et al., (2011) found significant decrease in ascorbic acid in different fruit juices (orange, lemon, lime and grapes) packaged in plastic bottles and stored at room temperature.

Viscosity of the drinks decreased significantly $(\mathrm{p}<0.05)$ from 1.58 to $1.40 \mathrm{cP}$ for control and 1.69 to $1.60 \mathrm{cP}$ for the experimental milk drink. Similar results for physicochemical changes were earlier observed by Kumar and Manimegalai (2005) in whey-based papaya juice blended ready to serve beverage stored at refrigerated temperature for three months. The antioxidant activity (per cent inhibition of $\mathrm{DPPH})$ decreased significantly $(\mathrm{p}<0.05)$ from
30.49 to 22.36 for control and 41.02 to 38.67 for experimental beverage. Similarly HMF concentration decreased significantly $(\mathrm{p}<0.05)$ from 136.86 to 110.48 for control and 141.95 to $119.33 \mu \mathrm{g} / 100 \mathrm{~g}$ for experimental beverage. Taherzadeh et al., (2000) found that HMF was used up and converted by the yeast during storage of beer, and the main conversion product was 5hydroxymethylfurfuryl alcohol (HMF alcohol).

The storage of soybean beverages caused a significant $(\mathrm{p}<0.05)$ decrease of antioxidant capacity, soluble phenolics, and isoflavone contents after 9 months at room temperature. When soybeans used for beverage production were stored for up to 6 months in silos, the resulting products were not affected. However, a decrease of malonyl and a proportional increase of free glucosidic forms of isoflavones were observed after storage of both the raw material and the experimental beverages (Rau et al., 2010). Similarly, a significant $(\mathrm{p}<0.05)$ decrease in antioxidant activity of Centella asiatica (gotu kola) drinks packaged in polypropylene and HDPE bottles was also noticed by Siah et al., (2011).

Table.1 Proximate composition of milk and mango pulp

\begin{tabular}{|l|l|l|}
\hline Component & Milk & Mango pulp \\
\hline Moisture (\%) & 88.67 & 78.36 \\
\hline Total solids (\%) & 11.70 & 21.64 \\
\hline Fat (\%) & 0.49 & 0.50 \\
\hline Protein (\%) & 3.22 & 0.70 \\
\hline Ash (\%) & 0.75 & 0.54 \\
\hline Total soluble solids ( $\left.{ }^{\circ} \mathrm{B}\right)$ & 12.0 & 18.00 \\
\hline Titratable acidity $(\%$ lactic acid) & 0.12 & $0.13 *$ \\
\hline pH & 6.57 & 4.80 \\
\hline
\end{tabular}

* as citric acid 
Table.2 Effect of storage on the physico-chemical characteristics of pasteurized mango based milk beverage

\begin{tabular}{|c|c|c|c|c|c|c|}
\hline \multirow{2}{*}{ Type of drink } & \multicolumn{6}{|c|}{ Storage (days) } \\
\hline & 0 & 2 & 4 & 6 & 8 & 10 \\
\hline \multicolumn{7}{|c|}{ Total solids (\%) } \\
\hline Control & 12.79 & 12.46 & 12.37 & 12.3 & 12.22 & 11.94 \\
\hline Milk beverage & 15.91 & 15.48 & 15.43 & 15.40 & 15.02 & 14.84 \\
\hline \multicolumn{7}{|l|}{ TSS $\left({ }^{\circ} \mathbf{B}\right)$} \\
\hline Control & 11.64 & 11.80 & 11.89 & 12.36 & 12.44 & 12.51 \\
\hline Milk beverage & 12.68 & 12.77 & 12.88 & 13.03 & 13.43 & 13.57 \\
\hline \multicolumn{7}{|c|}{ Titratable acidity (\% lactic acid) } \\
\hline Control & 0.126 & 0.127 & 0.129 & 0.131 & 0.135 & 0.136 \\
\hline Milk beverage & 0.139 & 0.142 & 0.145 & 0.149 & 0.203 & 0.236 \\
\hline \multicolumn{7}{|l|}{ pH } \\
\hline Control & 6.86 & 6.63 & 6.54 & 6.45 & 6.42 & 6.15 \\
\hline Milk beverage & 6.57 & 6.48 & 6.44 & 6.40 & 6.25 & 5.99 \\
\hline \multicolumn{7}{|c|}{ Reducing sugars (\%) } \\
\hline Control & 4.41 & 4.38 & 4.35 & 4.23 & 4.28 & 4.15 \\
\hline Milk beverage & 4.44 & 4.41 & 4.39 & 4.34 & 4.30 & 4.25 \\
\hline \multicolumn{7}{|c|}{ Ascorbic acid (mg/100 g) } \\
\hline Control & 1.287 & 1.247 & 1.225 & 1.029 & 0.986 & 0.935 \\
\hline Milk beverage & 1.661 & 1.535 & 1.528 & 1.416 & 1.207 & 0.943 \\
\hline \multicolumn{7}{|l|}{ Viscosity (cP) } \\
\hline Control & 1.59 & 1.56 & 1.52 & 1.49 & 1.44 & 1.39 \\
\hline Milk beverage & 1.63 & 1.61 & 1.58 & 1.55 & 1.51 & 1.46 \\
\hline \multicolumn{7}{|c|}{ Antioxidant activity (\% inhibition of DPPH) } \\
\hline Control & 30.89 & 30.60 & 30.50 & 28.70 & 26.36 & 25.19 \\
\hline Milk beverage & 42.39 & 41.62 & 41.41 & 40.24 & 39.56 & 39.06 \\
\hline \multicolumn{7}{|l|}{ HMF $(\mu \mathrm{g} / \mathbf{1 0 0 g})$} \\
\hline Control & 149.55 & 145.40 & 136.71 & 129.89 & 123.83 & 119.54 \\
\hline Milk beverage & 152.72 & 150.32 & 146.39 & 139.59 & 136.47 & 129.45 \\
\hline
\end{tabular}

\begin{tabular}{|c|c|c|c|c|c|c|c|c|c|c|}
\hline \multirow{3}{*}{ Source } & & \multicolumn{9}{|c|}{ ANOVA } \\
\hline & \multirow[t]{2}{*}{ df } & \multicolumn{9}{|c|}{ MSS } \\
\hline & & TS & TSS & $\begin{array}{c}\text { Titratable } \\
\text { acidity }\end{array}$ & $\mathrm{pH}$ & $\begin{array}{l}\text { Reducin } \\
\text { g Sugars }\end{array}$ & $\begin{array}{l}\text { Ascorbi } \\
\text { c acid }\end{array}$ & $\begin{array}{c}\text { Viscosit } \\
y\end{array}$ & $\begin{array}{l}\text { Antioxida } \\
\text { nt activity }\end{array}$ & $\mathrm{HMF}$ \\
\hline Storage (S) & 1 & 80.938 & 8.929 & 0.013 & 0.213 & 0.027 & 0.625 & 0.030 & 1297.074 & 625.722 \\
\hline Drink type (D) & 5 & 0.638 & 0.829 & 0.002 & 0.285 & 0.042 & 0.248 & 0.0278 & 20.453 & 643.766 \\
\hline S X D & 5 & 0.0242 & 0.008 & 0.002 & 0.0095 & 0.0017 & 0.0288 & 0.00025 & 2.2675 & 18.905 \\
\hline Error & 24 & 0.0710 & 0.0011 & 0.00001 & 0.0045 & 0.0019 & 0.00004 & 0.00033 & 0.0117 & 1.1736 \\
\hline
\end{tabular}


Table.3 Effect of storage on the sensory scores of pasteurized mango based milk beverage

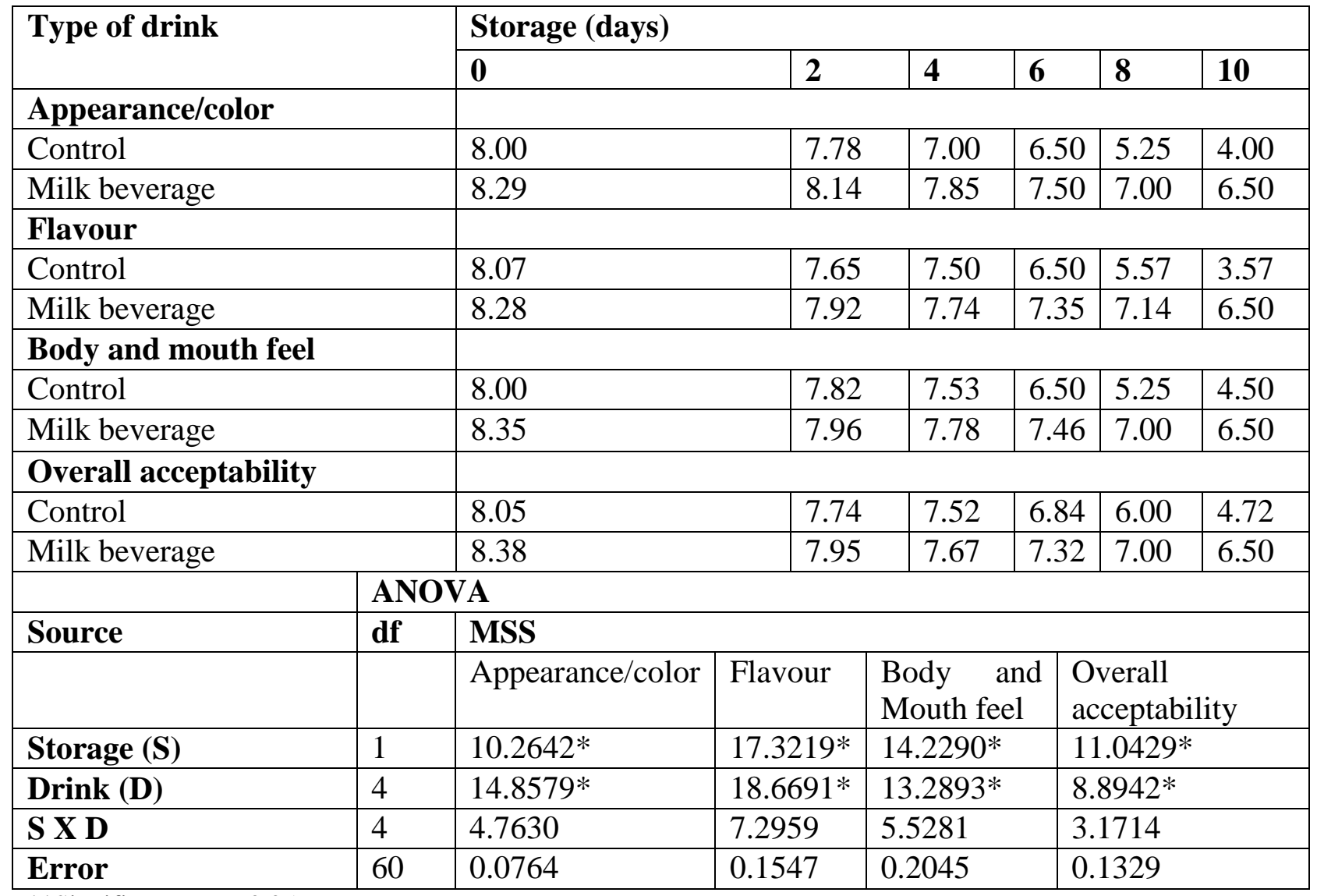

**Significant at $\mathrm{p}<0.05$

Table.4 Effect of storage on the microbial counts of pasteurized mango based milk beverage

\begin{tabular}{|c|c|c|c|c|c|c|}
\hline \multirow{2}{*}{ Type of drink } & \multicolumn{6}{|c|}{ Storage period (days) } \\
\hline & 0 & 2 & 4 & 6 & 8 & 10 \\
\hline \multicolumn{7}{|c|}{ Standard plate count $\left(\log _{10} \mathrm{cfu} / \mathrm{ml}\right)$} \\
\hline Control & ND & 3.40 & 4.02 & 4.29 & 4.39 & 4.45 \\
\hline Dairy beverage & ND & 2.23 & 2.82 & 3.21 & 3.84 & 3.96 \\
\hline \multicolumn{7}{|c|}{ Yeast and mold count $\left(\log _{10} \mathrm{cfu} / \mathrm{ml}\right)$} \\
\hline Control & ND & ND & 1.07 & 1.36 & 1.73 & 1.79 \\
\hline Dairy beverage & $\mathrm{ND}$ & ND & 1.12 & 1.42 & 1.84 & 1.90 \\
\hline \multicolumn{7}{|l|}{ ANOVA } \\
\hline \multirow[t]{2}{*}{ Source } & Df & \multicolumn{2}{|l|}{ MSS } & & & \\
\hline & & SPC & YMC & & & \\
\hline Storage (S) & 1 & $6.2935 * *$ & $0.0206^{* *}$ & & & \\
\hline Drink type (D) & 3 & $1.7202 * *$ & $0.7327 * *$ & & & \\
\hline SX D & 3 & 0.1634 & 0.0024 & & & \\
\hline Error & 16 & 0.00635 & 0.2162 & & & \\
\hline
\end{tabular}

$* *$ Significant at $\mathrm{p}<0.05, \mathrm{ND}$ : Not detected 
Fig.1 Process flow chart for the preparation of mango flavored milk beverage

Milk

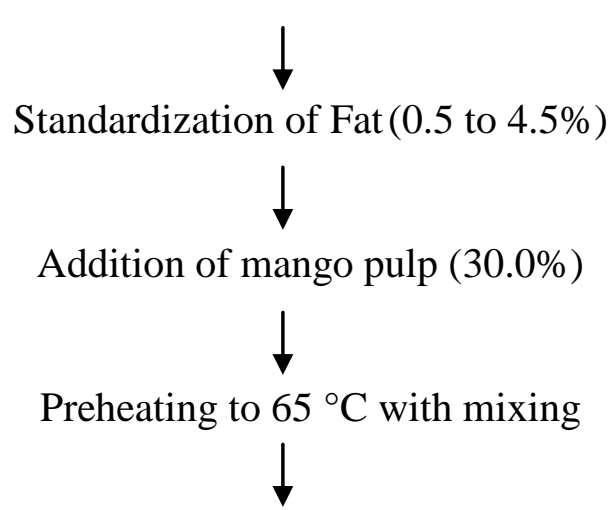

Filteration

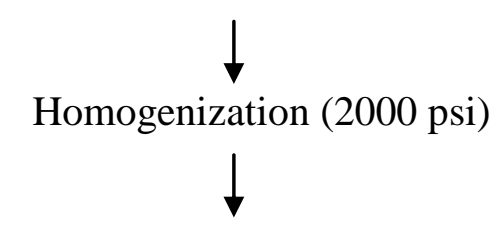

Bottling, sealing and labeling
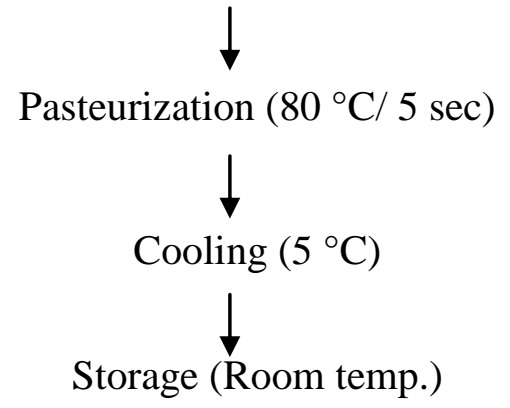

The pasteurized low calorie mango flavoured milk drinks prepared by replacing sugar with sucralose and adding 10 per cent mango pulp in milk of low fat content ( 0.5 per cent) recorded a significant $(p<0.01)$ loss in the viscosity, ascorbic acid and reducing sugar content during the storage period of 10 days at $5.0 \pm 0.1^{\circ} \mathrm{C}$. However, the titratable acidity increased to undesirable levels after 8 days making the drinks unacceptable (Mittal and Bajwa, 2013).

\section{Sensory evaluation}

The beverages prepared by blending of whey and pulp in different combination were analyzed for various sensorial attributes for their acceptance by using 9 point hedonic scale.
The sensory scores obtained with respect to color, flavor, taste and overall acceptability are presented in Table 3. The beverage packaged in HDPE sachets showed a significant $(\mathrm{p}<0.05)$ decrease in the scores of appearance/color from 8.00 to 4.00 and 8.29 to 6.50 , flavour scores from 8.07 to 3.57 and 8.28 to 6.50 , body and mouth feel from 8.00 to 4.00 and 8.35 to 6.50 for control and experimental samples, respectively. Thus the overall acceptability decreased significantly from 8.05 to 4.02 for control and 8.38 to 6.50 for beverage during the storage of ten days. The beverage remained acceptable to sensory panel for six days. Shekilango et al., (1997) also found that the characteristics like appearance, colour, flavor, taste and overall acceptability of sensory 
evaluation were in decreasing trend in a storage study of whey based mango beverage.

\section{Microbial analysis}

The beverage samples were analysis periodically for total plate count and yeast and mold count. The data obtained with respect to microbial load are summarized in Table 4. For the experimental beverage packaged in HDPE sachets, as the storage period preceded, the total plate count increased significantly $(\mathrm{p}<0.05)$ from $1.02 \times 10^{4}$ to $4.45 \times 10^{4} \mathrm{cfu} / \mathrm{ml}$ for control and from $1.24 \times 10^{4}$ to $3.96 \times 10^{4} \mathrm{cfu} / \mathrm{ml}$ for the milk experimental samples, respectively. Yeast and mould count increased significantly $(\mathrm{p}<0.05)$ from 1.01 to 1.09 (control) and 1.10 to $1.90 \mathrm{cfu} / \mathrm{ml}$ (experimental beverage) after ten days making the beverage unacceptable due to spoilage.

Esmail et al., (2011) noticed a significant $(p<0.05)$ rise in total viable count of wheybased mango beverage stored under refrigeration for nine days. In another experiment by Farah and Bachmann (1981), the bottled experimental beverage without any fruit pulp pasteurized at $75{ }^{\circ} \mathrm{C}$ for $30 \mathrm{sec}$ was microbiologically stable at $4^{\circ} \mathrm{C}$ for 21 days, but at room temperature spoilage occurred with the increase of bacterial count from $10^{4}$ to $10^{7}$ $\mathrm{cfu} / \mathrm{ml}$ and yeast mold count from 0.0 to $10^{4}$ cfu/ml. Khan and Malik (2002) observed that the total viable count in raw milk ranged between $10^{6}$ and $10^{7} \mathrm{cfu} / \mathrm{ml}$ and of pasteurized milks between $10^{4}$ and $10^{6} \mathrm{cfu} / \mathrm{ml}$, respectively. They also noticed that total viable count in fruit juices ranged from $10^{5}$ and $10^{7} \mathrm{cfu} / \mathrm{ml}$. Standard plate count and yeast and mold count was found to increase during storage of pasteurized low calorie mango flavoured milk drinks stored for period a of 10 days at $5.0 \pm 0.1^{\circ} \mathrm{C}$ (Mittal and Bajwa 2013).

It can be concluded that mango-based dairy beverage packaged in high density polyethylene and glass bottles, stored at refrigerated condition has a significant effect on physicochemical and sensory attributes. Gradual decrease in organoleptic properties and a significant rise in microbial content make the beverage unacceptable to the sensory panelists after six days of successful storage. A sharp increase in the acidity of beverage due to microbial growth may be attributed to the off flavor and bitter taste. A significant fall in the HMF concentration and resultant antioxidant activity of fruit based beverage may also be noticed as far as the functionality of the beverage is concerned.

\section{References}

AOAC (2000) Official methods of analyses. Association of Official Analytical Chemists, Washington DC.

APHA (1984) Method of microbiological examination of food. American Public Health Association, Washington.

BIS (1981) Method of test for determination of SNF (Solid-not-fat) in milk by the use of lactometer. IS: 10083, Bureau of Indian Standards, New Delhi.

Boghani A H, Raheem A and Hashmi S I (2012) Development and Storage Studies of Blended Papaya-Aloe vera Ready to Serve (RTS) Beverage. J Food Process Technol 3: 185

Esmail A E, Abdelgader M O and Azhari Ali A (2011) Microbial and Chemical Evaluation of Whey- based Mango Beverage. Advance J Food Sci Technol 3: 250-53.

Gagrani R L, Rathi S D and Ingle U M (1986) Preparation of fruit flavored beverage from whey. J Food Sci Technol 24: 9394.

Kumar M (2000) Physico-chemical characteristics of low-calorie lassi and flavoured dairy drink using fat replacer and artificial sweeteners. M.Sc. thesis, NDRI (Deemed University), Karnal, India. (Original not seen. Cited by George V, Arora S, Sharma V, Wadhwa B K, Sharma G S and Singh A K (2006) Sweeteners - analyses and stability- A review. Indian J Dairy Sci., 59: 351-58).

Mahale D P, Khade R G and Vaidya V K 
(2008) Microbiological Analysis of Street Vended Fruit Juices from Mumbai City, India. Int J Food Safety, 10: 31-34.

Meilgaard M, Civille G V and Carr B T (1999): Sensory evaluation techniques. CRC Press, Boca Raton, Florida, pp. 385-87.

Mittal S and Bajwa U (2013) Quality characteristics of no added sugar ready to drink milk supplemented with mango pulp. $J$ Food Sci Technol., DOI 10.1007/s13197-013-1184-7a.

Morales F J and Babbel M B (2002) Antiradical efficiency of Maillard reaction mixtures in a hydrophilic media. J Agric Food Chem, 50: 2788-92.

Nagar E G, Clowes G, Tudorica C M, Kuri V and Brennan C S (2002) Rheological quality and stability of yog-ice cream with added inulin. Int J Dairy Technol 55: 89-93.

Njoku P C, Ayuk A A and Okoye C V (2011) Temperature Effects on Vitamin C Content in Citrus Fruits. Pakistan J of Nut 10 (12): 1168-1169.

Ranganna S (1994) Handbook of analysis and quality control for fruits and vegetable products. Tata MaGraw hill Publishing Company Limited, New Delhi.

Rau De Almeida Callou K, Sadigov S, Lajolo F M and Genovese M I (2010) Isoflavones and antioxidant capacity of commercial soy-based beverages: effect of storage. Apr J Agric Food Chem 58: 4284-91. doi: 10.1021/jf904130z.

Ruck J A (1969) Chemical methods for analysis of fruit and vegetable products. Research station Summerland, B. C. Research branch, Canada, Department of Agriculture.
Sakhale B K, Pawar V N and Ranveer R C (2012) Studies on the Development and Storage of Whey based RTS Beverage from Mango cv. Kesar. J Food Process Technol 3: 148 . doi:10.4172/21577110.1000148

Shekilango S A, Jelen P and Bagdan G C (1997) Production of whey-banana beverages from acid whey and over ripe bananas. Milchwissenschaft 52: 209-12.

Siah H, Faridah M Z, Rahimah S, Mohd Tahir and Mohd Zain D (2011) Effects of packaging materials and storage on total phenolic content and antioxidant activity of Centella asiatica drinks. J Trop Agric Food Sci 39: 000- 000 W.M.

Sikder, B., Sarkar, K., Ray, P.R. and Ghatak, P.K. 2001. Studies on shelf-life of wheybased mango beverages. Beverage Food World 28: 53-54.

Singh S, Ladkhani B G, Kumar A and Mathur B N (1994) Development of whey based beverage. Indian J Dairy Sci 47: 586-90.

Singh W, Kapoor C M and Srivastava D N (1999) Standardization of Technology for the manufacture of guava-whey beverage. Indian J Dairy Sci 52: 268-71.

Snedecor G W and Cochran W G (1968) Statistical Methods. pp 339. Oxford and IBH Publishing Company, New Delhi.

Teotia M S, Kaur S and Berry S K (1997) Utilization of muskmelon ready to serve beverage from enzyme clarified juice. Indian Food Packer 51: 11-17.

Tepe, B., Sokmen, M., Akpulat, H.A. and Sokmen, A. (2006): Screening of the antioxidant potentials of six Salvia species from Turkey. Fd Chem., 95, 200204.

\section{How to cite this article:}

Preeti Shukla, Usha Bajwa and Suresh Bhise. 2017. Effect of Storage on Quality Characteristics of Pasteurized Mango Based Milk Beverage. Int.J.Curr.Microbiol.App.Sci. 6(11): 3446-3456. doi: https://doi.org/10.20546/ijcmas.2017.611.406 